\title{
Empagliflozin in the treatment of type 2 diabetes: evidence to date
}

\author{
This article was published in the following Dove Press journal: \\ Drug Design, Development and Therapy \\ 30 October 2015 \\ Number of times this article has been viewed
}

Jay H Shubrook'

Babak Baradar Bokaie ${ }^{2}$

Sarah E Adkins ${ }^{3}$

'Primary Care Department, Clinical Research and Diabetes Services, Touro University College of Osteopathic Medicine, Vallejo, CA, USA; ${ }^{2}$ The Diabetes Institute at Ohio University, Ohio University, Athens, $\mathrm{OH}$, USA; ${ }^{3}$ Pharmacy Practice and Administration, College of Pharmacy, Ohio State University, Athens, $\mathrm{OH}$, USA
Correspondence: Jay H Shubrook Primary Care Department, Clinical Research and Diabetes Services, Touro University College of Osteopathic Medicine, I 310 Club Drive, Mare Island, Vallejo, CA 94592, USA

Email jay.shubrook@tu.edu
Abstract: In the last decade, researchers have gained a greater understanding of the pathophysiologic mechanisms of type 2 diabetes as a chronic and progressive disease. One of the more recent treatment targets is the kidney. The kidneys become maladaptive in diabetes by increasing the reabsorption of glucose above the normal physiologic renal threshold. This discovery has led to the development of the sodium/glucose cotransporter 2 inhibitors (SGLT2). These agents readjust the renal threshold for glucose reabsorption to a lower level and decrease glucose reabsorption, while increasing urinary glucose when the glucose is above the renal threshold and subsequently lowering plasma glucose. The mechanism of action of the SGLT2 inhibitors is insulin independent, which makes them a novel treatment of diabetes. At the time of preparation of this manuscript, there were three SGLT2 inhibitors available in the US. This manuscript focuses on empagliflozin, the newest SGLT2 inhibitor, the trials in its development, and the clinical data available to date. Further, the authors propose future applications of empagliflozin, including in the treatment of type 1 diabetes, and its potential role in renoprotection.

Keywords: SGLT-2 inhibitors, empagliflozin, type 2 diabetes, kidneys, type 1 diabetes, glucosuria

\section{Introduction}

Type 2 diabetes mellitus (T2DM) has become a global pandemic. It is now estimated that nearly 387 million people have diabetes globally. ${ }^{1}$ Rates in developing countries are increasing due to the changes in rates of obesity and inactivity. Deaths from diabetes are projected to increase $50 \%$ worldwide by 2025 . Eighty percent of these deaths will occur in low and middle income countries. ${ }^{2}$ T2DM is a complex and progressive disease. Once thought of as only a disease of insulin resistance, it is now believed that there are at least eight pathologic processes that lead to type 2 diabetes. ${ }^{3}$ These include abnormal $\beta$-cell insulin secretion, excessive $\alpha$-cell glucagon production, abnormal incretin effect, insulin resistance at the peripheral tissues, increased hepatic glucose production, increased lipolysis, neurotransmitter dysfunction, and abnormal renal handling of hyperglycemia. ${ }^{3}$ Knowledge of these pathophysiologic mechanisms is critical in the development and use of targeted treatments that have complementary mechanisms of action.

Insulin resistance is usually maximal at the time a person is diagnosed with T2DM. $\beta$-cell dysfunction and failure become prominent defects in this progressive disease. As T2DM is a multisystemic and progressive disease, no single therapy is adequate for long-term control. Treatment must be multifactorial, and combination therapy is often necessary. Most of the current available treatments are insulin "centric", meaning that they need insulin production to provide therapeutic benefit. These therapies only have a therapeutic effect as long as there is measurable insulin production. One of the newly discovered pathophysiologic processes that can be treated is increased renal glucose reabsorption that occurs in diabetes. ${ }^{4}$ This treatment is novel because 
the kidney has not been a therapeutic target previously, and the mechanism of action is independent of insulin.

\section{Introduction to renal glucose physiology}

Plasma glucose is usually maintained in a relatively narrow range between 70 and $160 \mathrm{mg} / \mathrm{dL}$ (3.9 and $8.9 \mathrm{mmol} / \mathrm{L})$. This involves a delicate balance between glucose production (liver and kidney), intestinal absorption, renal reabsorption, and glucose utilization in tissues around the body. In a normal healthy adult, kidneys can filter $160-180 \mathrm{~g}$ of glucose/d (mean glucose $100 \mathrm{mg} / \mathrm{dL} \times 180 \mathrm{~L} / \mathrm{d}$ ). ${ }^{5,6}$ In euglycemic people, essentially all the filtered glucose is reabsorbed in the proximal convoluted tubule allowing the glucose to remain in circulation. The normal filtered glucose load in a person without diabetes is approximately $125 \mathrm{mg} / \mathrm{min}$, but can rise when the ambient glucose rises or if the glomerular filtration rate increases. The maximum renal threshold for glucose reabsorption occurs when the serum glucose is approximately 180-200 mg/dL. In these individuals, when the glucose exposure to the kidney exceeds $\geq 200 \mathrm{mg} / \mathrm{dL}$ (11.0 mmol/L), no additional glucose is reabsorbed and the excessive glucose is excreted in the urine. ${ }^{6}$

Glucose reabsorption is mediated by the sodium/glucose cotransporter (SGLT) proteins. This process is independent of insulin. ${ }^{7}$ The great majority of the filtered glucose $(90 \%)$ is reabsorbed in the first segment of the proximal convoluted tubule by SGLT2. SGLT2 is a low affinity but high capacity transporter. ${ }^{8}$ The remaining filtered glucose $(10 \%)$ is removed from the filtrate by SGLT1 in the distal aspect of the proximal convoluted tubule. SGLT1 is a high-affinity and low-capacity transporter. ${ }^{8}$ This mechanism allows for conservation of calories.

There are a number of SGLT proteins expressed throughout the body. ${ }^{8}$ SGLT1 is expressed in the small intestine and helps to regulate glucose and galactose absorption in the kidney as mentioned before. People who do not have functioning SGLT1 will suffer from significant gastrointestinal (GI) complications including severe diarrhea, while those without functioning SGLT2 appear to live normal lives despite increased glucosuria. The SGLT2 inhibitors work on the SGLT1 and SGLT2 proteins. Therefore, high selectivity toward SGLT2 may be pharmacologically beneficial. Dual blockade may provide an even greater therapeutic effect, but it will need to be balanced with the GI effects of SGLT1 blockade (Figure 1).

\section{Renal physiology in type $\mathbf{2}$ diabetes}

People with T2DM routinely experience both fasting and postprandial hyperglycemia, which is a result of a number of maladaptive physiological responses that include exaggerated hepatic and renal glucose production, impaired insulin secretion, and inefficient glucose uptake. ${ }^{3}$ Recently, the kidney's maladaptive response to chronic hyperglycemia has become a treatment target in diabetes.

Normal renal physiology dictates that all filtered glucose is reabsorbed. However, if the plasma glucose levels rise above $200 \mathrm{mg} / \mathrm{dL}(11 \mathrm{mmol} / \mathrm{L})$ as seen in diabetes, some glucose is excreted in the urine. As shown in diabetic mice, there is upregulation of SGLT2. This might contribute to the increased plasma glucose threshold before any glucose is seen in the urine. ${ }^{9}$

However, in mouse models of diabetes mellitus, there is upregulation of SGLT2 in response to chronic hyperglycemia, allowing more glucose reabsorption. ${ }^{10}$ Furthermore, there is also an increase in SGLT protein expression in diabetes. ${ }^{11}$ These combine to potentially increase the maximum renal glucose threshold which contributes to more glucose reabsorption, which maintains plasma hyperglycemia (Figure 2).

\section{Early attempts to address abnormal renal physiology via SGLT proteins}

More than 100 years ago, it was identified that a botanical agent could induce glucosuria. The active ingredient was later identified as phlorizin, a substance found in the bark of apple trees. $^{12,13}$ Unfortunately, phlorizin had a number of significant limitations that made it unviable as a pharmacologic treatment. It had little selectivity for SGLT2 over SGLT1. The SGLT1 activity resulted in significant GI side effects. Further, phlorizin has an $O$-glucosidase which makes it susceptible to degradation by the $\beta$-glucosidase in the intestine, so it required IV dosing. ${ }^{14}$

Empagliflozin is structurally similar to phlorizin but with some important differences. It has a C-glucoside with a carbon-carbon bond between the glucose and aglycone moiety. This makes it resistant to degradation in the GI tract, allowing it to be orally administered. ${ }^{15}$ Further, because empagliflozin (EMPA) is highly selective for SGLT2 ( $>2,500$-fold), it is less likely to have GI side effects. ${ }^{7}$

The glucosuric effects of SGLT2 blockade raised early concerns about the safety of chronic high glucose levels in the renal tubules and in the urine. In familial renal glucosuria, people have nonfunctioning SGLT2 proteins from a mutation of the SLC5A2 gene that encodes SGLT2. These patients have chronic glucosuria even in the face of normoglycemia. Individuals with this condition rarely suffer from glucose-related problems and have no known renal 


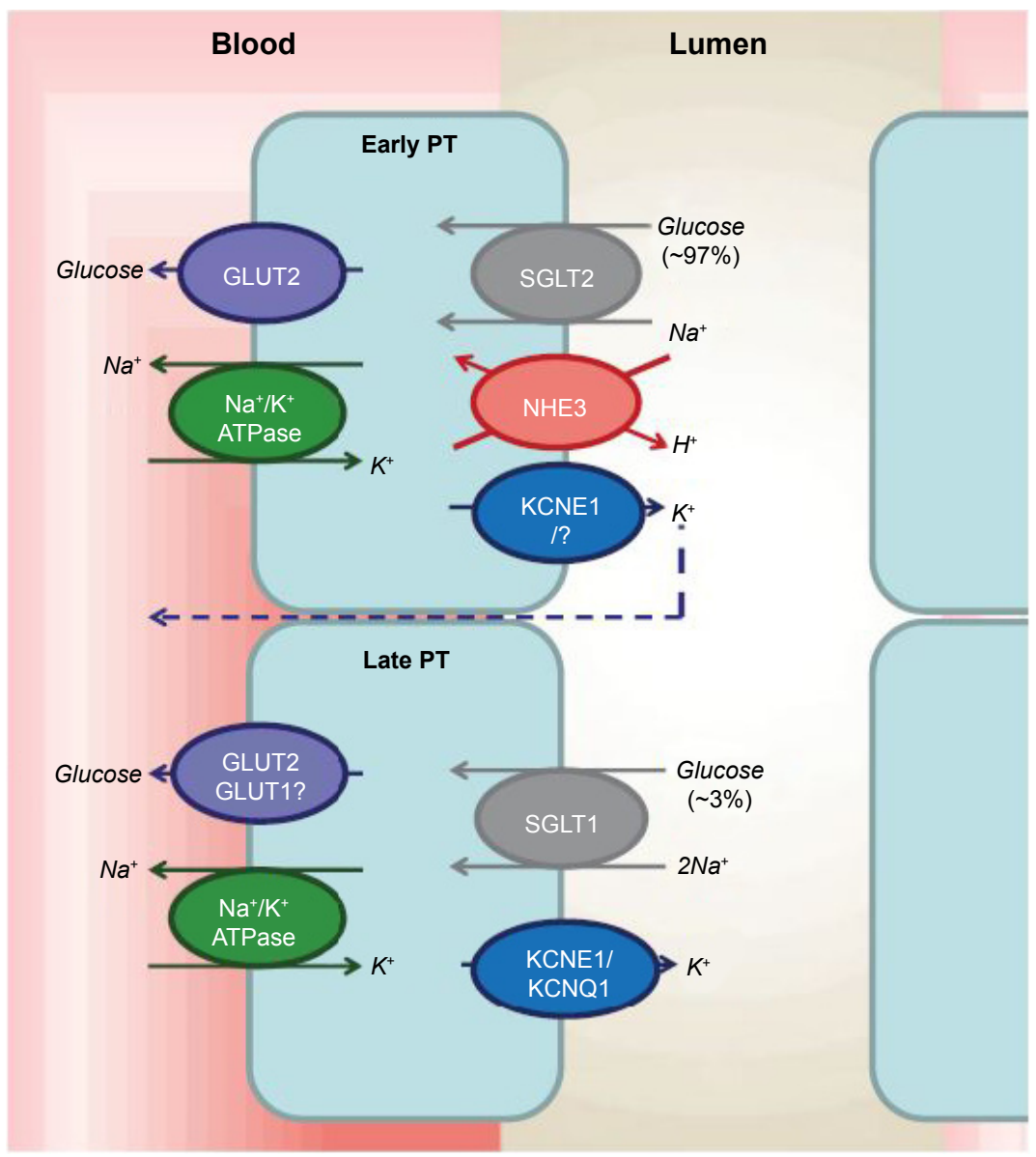

Figure I Physiology of glucose reabsorption in the proximal convoluted tubule.

Note: Reproduced from Gallo LA, Wright EM, Vallon V. Probing SGLT2 as a therapeutic target for diabetes: basic physiology and consequences. Diab Vasc Dis Res. 2015;12(2):78-89, ${ }^{6}$ copyright $@ 2015$ by (SAGE Publications). Reprinted by Permission of SAGE Publications, Ltd.

Abbreviations: GLUT, glucose transporter; PT, proximal tubule; KCNEI, potassium voltage-gated channel Isk-related family member I; KCNQI, potassium voltage-gated channel KQT-like subfamily member I; SGLT, sodium-dependent glucose transporter.

tubular dysfunction and typically do not report increased genitourinary infections. ${ }^{16}$

Conversely, loss of function of SGLT1 from a mutation of SLC5A1 results in little to no glucosuria but significant GI symptoms because of the glucose-galactose malabsorption that results in watery diarrhea and potentially dehydration. ${ }^{17}$ Thus, preferential targeting SGLT2 proteins (rather than SGLT1) with pharmacologic intervention is preferable.

\section{SGLT2 inhibitors}

The SGLT2 inhibitors are a new drug class that address hyperglycemia by reducing renal glucose reabsorption, increasing urinary glucose excretion, and consequentially reducing serum glucose levels. ${ }^{18,19}$ The SGLT2 inhibitors work independent of insulin (both secretion and sensitivity), which makes this class novel and potentially complementary to most current diabetes therapies.

There are currently three SGLT2 inhibitors available in the US. Canagliflozin was approved by the US Food and
Drug Administration (FDA) in March 2013 (FDA news release 2013), ${ }^{20}$ dapagliflozin in January 2014, and EMPA in August of 2014. ${ }^{21}$ All of these agents are potent competitive inhibitors of the SGLT2 protein, but dapagliflozin and EMPA are highly selective for SGLT2, while canagliflozin has dual blockade of SGLT1 and SGLT2. Of the three commercially available SGLT2 inhibitors, EMPA has the highest selectivity for SGLT2 (>2,500-fold) compared to SGLT1. ${ }^{22}$ The chemical structure for EMPA is shown in Figure 3.

\section{Preclinical studies}

Preclinical studies showed that EMPA is a competitive inhibitor of the SGLT2, has high specificity to SGLT2, and has a half-life of approximately 60 minutes. Early cell line studies demonstrated that EMPA is a potent inhibitor of SGLT2 and has $>2,500$-fold sensitivity for inhibition of SGLT2 vs SGLT1..$^{23}$ Subsequent rodent studies showed that EMPA reduced blood glucose in a dose-dependent manner by increasing urinary glucose excretion. ${ }^{22}$ In one 5 -week 


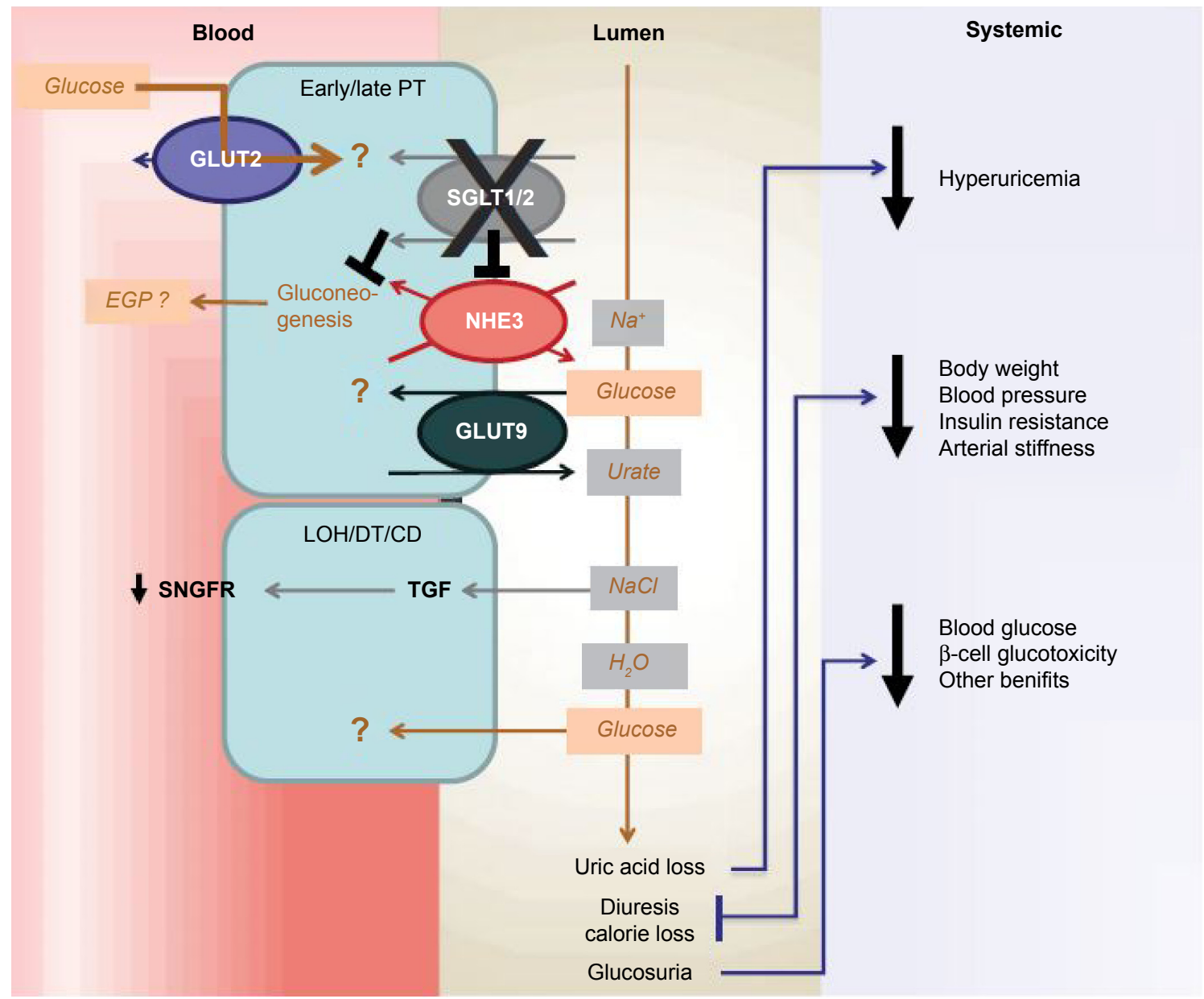

Figure 2 Downstream renal effects of SGLTI and SGLT2 inhibition.

Note: Reproduced from Gallo LA, Wright EM, Vallon V. Probing SGLT2 as a therapeutic target for diabetes: basic physiology and consequences. Diab Vasc Dis Res. 2015;12(2):78-89, ${ }^{6}$ copyright (C20I5 by (SAGE Publications). Reprinted by Permission of SAGE Publications, Ltd.

Abbreviations: GLUT, glucose transporter; SGLT, sodium glucose transporter; PT, proximal tubule; LOH, loop of Henle; DT, distal tubule; CD, collecting duct; NHE3, sodium hydrogen exchanger-3; EGP, endogenous glucose production; SNGFR, single nephron glomerular filtration rate; TGF, tubuloglomerular feedback.

trial, EMPA reduced $\mathrm{HbA}_{1 \mathrm{c}}$ levels by $0.3 \%(1 \mathrm{mg} / \mathrm{kg})$ and $1.1 \%(3 \mathrm{mg} / \mathrm{kg}) .^{24}$

\section{Human Phase I studies}

A single dose of EMPA was studied in 72 healthy males. ${ }^{25}$ Subjects were randomized to placebo or a dose of EMPA between 0.5 and $800 \mathrm{mg}$. EMPA was quickly absorbed with a maximum plasma concentration at approximately 1.5-2.1 hours, with drug exposure proportional to the dose administered. EMPA had a biphasic decline in concentration in the decay phase, with a terminal half-life from 8.6-13.1 hours. ${ }^{22}$ In these studies, the urinary glucose excretion increased to a maximum at the $50 \mathrm{mg}$ dose, significantly higher than placebo. ${ }^{25}$ Food and postprandial state had no effect on drug absorption, and glucosuria was similar after meals in these healthy subjects. All side effects were similar to placebo (headaches, GI, and nervous system disorders) and were not dose dependent. One hypoglycemic event was reported (glucose $53 \mathrm{mg} / \mathrm{dL}$ [2.9 mmol/L]) during a 3-hour glucose tolerance test.

Another series of Phase I trials tested EMPA 1-100 mg in 48 healthy Japanese men. ${ }^{26}$ In these studies, EMPA was rapidly absorbed with a maximum concentration at around 1.25-2.5 hours, with drug exposure and clearance relative to the dose administered. EMPA exposure was approximately 1.5 times higher in this study possibly due to differences in body weight between the population studies. The urinary glucose clearance was dose dependent as well. EMPA was<smiles>OC[C@H]1OC(c2ccc(Cl)c(Cc3ccc(O[C@H]4CCOC4)cc3)c2)[C@H](O)[C@H](O)[C@@H]1O</smiles>

Figure 3 Chemical structure of empagliflozin (Jardiance ${ }^{\circledR}$ ). 
well tolerated (mild side effects, not dose dependent), and no hypoglycemia was reported.

Finally, the pharmacokinetic (PK) and pharmacodynamics (PDs) profiles of EMPA were determined after the first dose on day 1 and at steady state dosing on day 28. EMPA was rapidly absorbed with peak concentration at 1.5 hours. Clearance was biphasic with a range of 13.2-16.5 hours. Oral clearance showed linear PKs in terms of time. Eighteen percent of the medication was excreted in the urine unchanged. The urinary glucose excretion was dose dependent. Compared to baseline, urinary glucose excretion increased to $74 \mathrm{~g}$ in the $10 \mathrm{mg}$ dose, $90 \mathrm{~g}$ in the $25 \mathrm{mg}$ dose, and $81 \mathrm{~g}$ in the $100 \mathrm{mg}$ dose. There was essentially no change in urinary glucose excretion in the placebo group. Urinary glucose excretion remained constant throughout the study. No significant changes in urine volume were reported. There were significant reductions in fasting and post oral glucose tolerance test glucose readings on day 28 compared to placebo. A nonsignificant reduction in $\mathrm{HbA}_{1 \mathrm{c}}$ was seen in the EMPA groups at 28 days (Table 1). ${ }^{27,28}$

\section{Phase II trials}

A study evaluated the safety, tolerability, and PK/PD in 78 people with type 2 diabetes. ${ }^{27}$ Subjects were randomized to EMPA $(10,25,100 \mathrm{mg})$ or placebo. Weighted randomization was completed for the $100 \mathrm{mg}$ dose ( $2 \times$ other groups) to assess the safety of this dose. The plasma concentration and urinary glucose excretion were dose dependent. Urinary glucose excretion remained elevated throughout the trial compared to no increase in the placebo-treated group. Side effects were similar in the treatment arms, with the most common adverse effects being pollakiuria $(10.3 \%)$, nasopharyngitis $(9.0 \%)$, constipation $(9.0 \%)$, and headache $(7.7 \%)$. Urinary-related adverse effects were more common in the EMPA groups.

Table I Summary of key pharmacokinetic parameters of empagliflozin 10 and $25 \mathrm{mg}$ at steady state after oral dosing

\begin{tabular}{|c|c|c|}
\hline \multirow{2}{*}{$\begin{array}{l}\text { Pharmacokinetic } \\
\text { parameters }\end{array}$} & \multicolumn{2}{|c|}{ Empagliflozin dose } \\
\hline & $10 \mathrm{mg} \mathrm{qd}(\mathrm{n}=8)$ & $25 \mathrm{mg}$ qd $(\mathrm{n}=9)$ \\
\hline $\mathrm{AUC}_{0-t}, \mathrm{ss}(\mathrm{nmol} \mathrm{h} / \mathrm{L})$ & $2,030(362)$ & $4,990(1,080)$ \\
\hline$C_{\max }$, ss $(\mathrm{nmol} h / \mathrm{L})$ & $283(90.1)$ & $630(106)$ \\
\hline$t_{\max }$, ss $(\mathrm{h})^{\mathrm{a}}$ & $1.5(1.0-2.0)$ & $2.0(0.7-4.2)$ \\
\hline$t_{1 / 2}$, ss $(\mathrm{h})$ & I4.3 (2.4) & $10.7(2.1)$ \\
\hline $\mathrm{Fe}_{0-24}$, ss $(\%)$ & $18.7(4.5)$ & $12.7(6.4)$ \\
\hline CLR, $t, \mathrm{ss}(\mathrm{mL} / \mathrm{min})$ & 34.4 (7.9) & $23.5(8.7)$ \\
\hline
\end{tabular}

Notes: Data are mean (SD) unless otherwise indicated. aMedian (range) is denoted. Reproduced from McGill J. The SGLT2 inhibitor empagliflozin for the treatment of type 2 diabetes mellitus: a bench to bedside review. Diabetes Ther. 20। 4;5:43-63. ${ }^{57}$ Abbreviations: AUC, area under concentration-time curve; $C_{\max }$, maximum plasma concentration; $C L R$, renal clearance; $F$ e, fraction of dose that was excreted unchanged in urine; qd, once daily; SD, standard deviation; ss, steady state; $t$, dosing interval; $t_{1 / 2}$, terminal half-life in plasma; $t_{\max }$, time to maximum plasma concentration.
In another study, investigators randomized 408 treatment naïve (or 4-week washout) subjects with type 2 diabetes to EMPA $25 \mathrm{mg}$, metformin, or placebo. The overall mean $\mathrm{A}_{1 \mathrm{c}}$ was $7.9 \% \pm 0.8 \%$ at entry. All EMPA doses had significant $\mathrm{A}_{1 \mathrm{c}}$ reductions compared to placebo (placebo $+0.1 \%$; EMPA $5 \mathrm{mg},-0.4 \%$; $10 \mathrm{mg},-0.5 \% ; 25 \mathrm{mg},-0.6 \%$; all $P<0.0001$ ) and showed similar reduction as compared with metformin $(-0.7 \%))^{29}$

A trial evaluated the PK/PD of a single dose of $50 \mathrm{mg}$ of EMPA in 40 patients with various levels of renal impairment. The peak concentration was similar to previous studies, but the total plasma exposure and maximum concentration were slightly elevated in those with advanced renal impairment. In this study, the greater the renal impairment, the lower the urinary glucose excretion. ${ }^{30}$

There was some initial concern about hepatic safety in early studies with dapagliflozin. In a similar set of studies with EMPA (as already mentioned), there did not appear to be any dose adjustment needed in people with mild, moderate, or severe hepatic impairment. ${ }^{31}$ These studies are summarized in Table 2.

Some small studies have reported an increase in endogenous glucose production with SGLT2 inhibitors including EMPA. ${ }^{32-34}$ The elevated hepatic glucose production appears to be a compensatory response to support normal plasma glucose levels in the presence of sustained urinary glucose excretion. The plasma glucagon/insulin ratio is a regulator of hepatic glucose production and so the increase in glucagon could explain the rise in hepatic glucose production observed with SGLT2 inhibition. ${ }^{33}$ Overall, glucose levels are still decreased despite the increase in glucose production. Further investigation is needed to determine the long-term significance of this physiologic response and optimal therapeutic approach.

\section{Clinical benefits of empagliflozin in Phase III trials}

Empagliflozin has been studied as a monotherapy and in combination therapy for type 2 diabetes. $\mathrm{A}_{1 \mathrm{c}}$ reduction with EMPA $10 \mathrm{mg}(-0.66 \%)$ or $25 \mathrm{mg}(-0.78 \%)$ was statistically superior to that observed with placebo $(0.08 \%)$ when given as monotherapy. ${ }^{35} \mathrm{~A}_{1 \mathrm{c}}$ reduction with EMPA 10 and 25 $\mathrm{mg}$ was similar to $A_{1 \mathrm{c}}$ reduction with sitagliptin $100 \mathrm{mg} .{ }^{35}$ In this study, body weight decreased significantly with EMPA $10 \mathrm{mg}(-2.26 \mathrm{~kg})$ and $25 \mathrm{mg}(-2.46 \mathrm{~kg})$ compared to placebo $(-0.33 \mathrm{~kg})$. Finally, systolic blood pressure (SBP) decreased significantly with EMPA $10 \mathrm{mg}(-2.9$ $\mathrm{mmHg})$ and $25 \mathrm{mg}(-3.7 \mathrm{mmHg})$ compared to placebo $(-0.3 \mathrm{mmHg})$. 
Table 2 Empagliflozin pharmacokinetics after administration of a single $50 \mathrm{mg}$ dose in patients with renal or hepatic impairment

\begin{tabular}{|c|c|c|}
\hline Impairment severity & Total plasma exposure $A \cup C_{0-\infty}(\mathrm{nmol} h / \mathrm{L})$ & $C_{\max }$, ss $(\mathrm{nmol} / \mathrm{L})$ \\
\hline \multicolumn{3}{|l|}{ Renal impairment study ${ }^{57}$} \\
\hline Mild $(n=9)$ & $118.2 \%(96.2,145.4)$ & $118.8 \%(93.6,150.8)$ \\
\hline Moderate $(n=7)$ & $119.9 \%(96.3,149.5)$ & $102.3 \%(79.3,131.9)$ \\
\hline Severe $(n=8)$ & $166.3 \%(134.4,205.7)$ & $120.7 \%(94.4,154.3)$ \\
\hline Failure/ESRD $(\mathrm{n}=8)$ & $148.3 \%(|19.9| 83.4)$, & $103.8 \%(8|.2| 32.6)$, \\
\hline \multicolumn{3}{|c|}{ Hepatic impairment study ${ }^{30}$} \\
\hline Mild $(n=8)$ & $123.15 \%(98.9,153.4)$ & $103.8 \%(82.3,|3| .0)$ \\
\hline Moderate $(n=8)$ & $146.97 \%(\mid 18.0,183.0)$ & $123.3 \%(97.7,155.6)$ \\
\hline Severe $(n=8)$ & $174.70 \%(\mid 40.3,217.6)$ & $148.4 \%(\mid 17.7,187.2)$ \\
\hline
\end{tabular}

Notes: For both studies, values are adjusted GMR (impaired/normal group), with $90 \% \mathrm{Cl}$ for adjusted GMR. Reproduced from McGill J. The SGLT2 inhibitor empagliflozin for the treatment of type 2 diabetes mellitus: a bench to bedside review. Diabetes Ther. 20I4;5:43-63. ${ }^{57}$

Abbreviations: AUC, area under the concentration-time curve; $\mathrm{Cl}$, confidence interval; $C_{\max }$, ss, maximum plasma concentration at steady state; ESRD, end-stage renal disease; GMR, geometric mean ratio.

Nearly two-thirds of the subjects in this study entered the extension phase of the study for an additional 52 weeks for a total of 76 weeks. The placebo-subtracted $\mathrm{A}_{1 \mathrm{c}}$ reductions at 76 weeks were $0.78 \%$ for EMPA $10 \mathrm{mg}, 0.89 \%$ for EMPA $25 \mathrm{mg}$, with persistent weight loss of $1.8 \mathrm{~kg}$ with $10 \mathrm{mg}$ of EMPA and $2.0 \mathrm{~kg}$ for $25 \mathrm{mg}$ of EMPA and SBP reductions of $3.4 \mathrm{mmHg}$ in both the 10 and $25 \mathrm{mg}$ arms of EMPA. ${ }^{36}$

As add-on therapy to metformin, EMPA $25 \mathrm{mg}$ has been shown to be statistically superior to glimepiride in a 104-week study. ${ }^{37}$ The $\mathrm{A}_{1 \mathrm{c}}$ reduction was $0.66 \%$ with EMPA and $0.55 \%$ with glimepiride. Weight and blood pressure were reduced with EMPA $(-3.1 \mathrm{~kg},-3.1 \mathrm{mmHg})$, and these changes were not seen with glimepiride $(+1.3 \mathrm{~kg},+2.1 \mathrm{mmHg})$.

When EMPA was given in combination with other medications, there were significant improvements in $\mathrm{HbA}_{1 \mathrm{c}}$. Table 3 provides an overview of EMPA with metformin ${ }^{38,39}$ metformin plus a sulfonylurea, ${ }^{38}$ pioglitazone or pioglitazone plus metformin, ${ }^{40}$ or multidose insulin with or without metformin. ${ }^{41}$

Statistically significant reductions in body weight and SBP (relative to placebo) were also found in EMPA combination studies. These studies included combinations with metformin, ${ }^{37-40}$ with metformin plus a sulfonylurea, ${ }^{37}$ and with pioglitazone or pioglitazone plus metformin. ${ }^{40}$ When EMPA $10 \mathrm{mg}$ or $25 \mathrm{mg}$ were added to multidose insulin with or without metformin, there was a statistically significant reduction in body weight but a nonsignificant reduction in SBP..$^{41}$ In combination with metformin, EMPA $25 \mathrm{mg}$ resulted in statistically significant reductions in body weight and SBP compared with glimepiride. ${ }^{39}$

EMPA in combination studies resulted in small increases in low-density lipoprotein cholesterol (LDL-C) and high-density lipoprotein cholesterol (HDL-C). When EMPA was added to metformin plus pioglitazone, there were small increases in HDL-C in placebo-controlled studies: $0.06 \mathrm{mmol} / \mathrm{L}(2.32 \mathrm{mg} / \mathrm{dL})$ with EMPA $10 \mathrm{mg}$ and $0.03 \mathrm{mmol} / \mathrm{L}(1.16 \mathrm{mg} / \mathrm{dL})$ with EMPA $25 \mathrm{mg} .{ }^{37}$ With metformin only, increases in HDL-C of $0.08 \mathrm{mmol} / \mathrm{L}$ $(3.09 \mathrm{mg} / \mathrm{dL})$ and $0.06 \mathrm{mmol} / \mathrm{L}(2.32 \mathrm{mg} / \mathrm{dL})$ with EMPA 10 and $25 \mathrm{mg}$, respectively, were seen relative to placebo. ${ }^{36}$ EMPA as an add-on to metformin has been reported to result in small increases in LDL-C (adjusted mean increase $0.15 \mathrm{mmol} / \mathrm{L}$ ). ${ }^{40}$ Finally, Phase III studies with EMPA have shown reductions in plasma uric acid. $33,35,37$ This may be clinically important in that hyperuricemia has been identified as an independent risk factor for cardiovascular disease. ${ }^{42}$

EMPA was also studied in people with moderate renal insufficiency. EMPA $25 \mathrm{mg}$ resulted in an adjusted mean placebo subtracted $\mathrm{A}_{1 \mathrm{c}}$ change of $-0.42 \%$ at week 24 in patients with estimated glomerular filtration rate $(\mathrm{eGFR}) \geq 30$ to $<60 \mathrm{~mL} / \mathrm{min} / 1.73 \mathrm{~m}^{2}{ }^{43}$ In patients with stage 2 and 3 chronic kidney disease, EMPA resulted in significant reductions of $\mathrm{A}_{1 \mathrm{c}}$, body weight, and SBP compared with placebo after 52 weeks. ${ }^{43}$

Results from these EMPA studies are consistent with results seen from other agents within the class. A systematic review and meta-analysis of clinical trials comparing an SGLT2 inhibitor with placebo ( 45 studies, $\mathrm{n}=11,232$ ) or an active comparator ( 13 studies, $n=5,175)$ reported improved glycemic control, reduced body weight, and reduced blood pressure with SGLT2 inhibitor therapy. ${ }^{44}$

\section{Safety of empagliflozin}

The most frequently occurring adverse events with EMPA are urinary tract infections (7.6\% with placebo vs $9.3 \%$ and $7.6 \%$ with EMPA 10 and $25 \mathrm{mg}$, respectively) and genital mycotic infections (in female patients: $1.5 \%$ with placebo vs $5.4 \%$ and $6.4 \%$ with EMPA 10 and $25 \mathrm{mg}$, respectively). ${ }^{23}$ Adverse events related to osmotic diuresis and volume contraction 
Table 3 Efficacy and safety of EMPA in randomized, double-blind Phase III trials of patients with type 2 diabetes mellitus

\begin{tabular}{|c|c|c|c|c|c|c|c|}
\hline \multirow[t]{2}{*}{ Study } & \multirow[t]{2}{*}{ Regimen and duration } & \multicolumn{3}{|l|}{ Efficacy } & \multicolumn{3}{|l|}{ Safety } \\
\hline & & $A_{I c}(\%)$ & $\begin{array}{l}\text { Body } \\
\text { weight (kg) }\end{array}$ & $\begin{array}{l}\text { SBP } \\
(\mathrm{mmHg})\end{array}$ & UTIs (\%) & $\begin{array}{l}\text { Events consistent } \\
\text { with GMIs (\%) }\end{array}$ & $\begin{array}{l}\text { Events consistent } \\
\text { with UTIs (\%) }\end{array}$ \\
\hline \multicolumn{8}{|l|}{ Monotherapy } \\
\hline \multirow[t]{4}{*}{ Roden et $\mathrm{a}^{35}$} & EMPA $10 \mathrm{mg}(\mathrm{n}=224)$ & -0.66 & -2.26 & -2.9 & 6 & $3 \mathrm{M}, 4 \mathrm{~F}$ & $2 \mathrm{M}, \mathrm{I} 5 \mathrm{~F}$ \\
\hline & EMPA 25 mg $(n=87)$ & -0.78 & -2.48 & -3.7 & 4 & I M, $9 \mathrm{~F}$ & $\mathrm{I} \mathrm{M}, \mathrm{I3} \mathrm{F}$ \\
\hline & PBO $(n=228)$ & 0.08 & -0.33 & -0.3 & 4 & $0 \mathrm{M}, 0 \mathrm{~F}$ & $2 \mathrm{M}, 9 \mathrm{~F}$ \\
\hline & 24 weeks & & & & & & \\
\hline \multicolumn{8}{|c|}{ Combination therapy } \\
\hline \multirow[t]{5}{*}{ Häring et $\left.a\right|^{37}$} & MET + SU + one of: & & & & & & \\
\hline & EMPA 10 mg $(n=225)$ & -0.82 & -2.16 & -4.1 & 9.4 & $0.9 \mathrm{M}, 4.5 \mathrm{~F}$ & $2.7 \mathrm{M}, 18.0 \mathrm{~F}$ \\
\hline & EMPA 25 mg $(n=216)$ & -0.77 & -2.39 & -3.5 & 6.9 & $0.9 \mathrm{M}, 3.9 \mathrm{~F}$ & $0 \mathrm{M}, \mathrm{I} 7.5 \mathrm{~F}$ \\
\hline & $\mathrm{PBO}(\mathrm{n}=225)$ & -0.17 & -0.39 & -1.4 & 6.7 & $0.9 \mathrm{M}, 0.9 \mathrm{~F}$ & $2.7 \mathrm{M}, \mathrm{I} 3.3 \mathrm{~F}$ \\
\hline & 24 weeks & & & & & & \\
\hline \multirow[t]{5}{*}{ Häring et $\mathrm{al}^{38}$} & MET + one of: & & & & & & \\
\hline & EMPA $10 \mathrm{mg}(\mathrm{n}=2 \mid 7)$ & -0.70 & -2.08 & -4.5 & 5.1 & $0.8 \mathrm{M}, 7.6 \mathrm{~F}$ & $0 \mathrm{M}, \mathrm{I} 2.0 \mathrm{~F}$ \\
\hline & EMPA 25 mg $(n=2 \mid 3)$ & -0.77 & -2.46 & -5.2 & 5.6 & $0.8 \mathrm{M}, 9.7 \mathrm{~F}$ & $0.8 \mathrm{M}, \mathrm{I} \mathrm{I} .8 \mathrm{~F}$ \\
\hline & PBO $(n=207)$ & -0.13 & -0.45 & -0.4 & 4.9 & $0 \mathrm{M}, 0 \mathrm{~F}$ & $2.6 \mathrm{M}, 7.7 \mathrm{~F}$ \\
\hline & 24 weeks & & & & & & \\
\hline \multirow[t]{4}{*}{ Ridderstråle et al ${ }^{39}$} & MET + one of: & & & & & & \\
\hline & EMPA 25 mg $(n=765)$ & -0.66 & -3.1 & -3.1 & 14 & $9 \mathrm{M}, \mathrm{I5} \mathrm{F}$ & $7 \mathrm{M}, 22 \mathrm{~F}$ \\
\hline & GLIM I-4 mg $(n=780)$ & -0.55 & 1.3 & 2.5 & 13 & I M, 3 F & $5 \mathrm{M}, 23 \mathrm{~F}$ \\
\hline & I04 weeks & & & & & & \\
\hline \multirow[t]{5}{*}{ Kovacs et al ${ }^{40}$} & $\mathrm{PIO} \pm \mathrm{MET}+$ one of: & & & & 1 & & \\
\hline & EMPA $10 \mathrm{mg}(\mathrm{n}=165)$ & -0.59 & -1.62 & -3.14 & 4.5 & $7.2 \mathrm{M}, 9.8 \mathrm{~F}$ & $3.6 \mathrm{M}, 30.5 \mathrm{~F}$ \\
\hline & EMPA $25 \mathrm{mg}(n=168)$ & -0.72 & -1.47 & -4.00 & 10.7 & $1.2 \mathrm{M}, 6.0 \mathrm{~F}$ & $2.4 \mathrm{M}, 21.7 \mathrm{~F}$ \\
\hline & PBO $(n=165)$ & -0.11 & 0.34 & 0.72 & 10.9 & I.4 M, $3.3 \mathrm{~F}$ & $8.2 \mathrm{M}, 22.8 \mathrm{~F}$ \\
\hline & 24 weeks & & & & & & \\
\hline
\end{tabular}

Note: Adapted with permission from Miller E, Shubrook JH. Role of the kidneys and sodium glucose co-transporter 2 (sglt2) inhibitors in the treatment of type 2 diabetes mellitus. Osteopathic Family Physician. 2015; I(5): 10-30.58 Copyright (C) 2015.

Abbreviations: EMPA, empagliflozin; F, female; GLIM, glimepiride; GMI, genital mycotic infections; M, male; MET, metformin; PBO, placebo; PIO, pioglitazone; SBP, systolic blood pressure; SU, sulfonylurea; UTI, urinary tract infection.

have been evaluated from pooled data from Phase I, II, and III studies in $>11,000$ patients. ${ }^{45}$ In that analysis, the overall incidence of volume depletion events was $1.4 \%$ with EMPA $10 \mathrm{mg}$ and $1.5 \%$ with EMPA $25 \mathrm{mg}$ vs $1.4 \%$ with placebo. The incidence of these events was higher in subjects aged $\geq 75$ years, those with eGFR $<30 \mathrm{~mL} / \mathrm{min} / 1.73 \mathrm{~m}^{2}$, and those also receiving diuretic therapy. ${ }^{21}$

Increased rates of hypoglycemia were not seen in EMPA monotherapy or in combination with insulin sensitizers. However, when combined with other medications that have a high risk of hypoglycemia (sulfonylureas or insulin), the EMPA arms of these studies had higher rates of hypoglycemia. ${ }^{38,40,41}$

\section{Recent updates Empagliflozin and glucagon}

Ferrannini et $\mathrm{al}^{34}$ demonstrated that those people with type 2 diabetes who took an SGLT2 inhibitor had an increase in glucagon and hepatic glucose production. This has a potential explanation (that Bonner et $\mathrm{al}^{46}$ recently published) in that there is SGLT2 expression in the $\alpha$-cells in the pancreas.
This will need further investigation. Clinically, it may be important to pair SGLT2 inhibitors that counteract this increase in glucagon such as dipepitdyl-peptidase -4 inhibitor (DPP-4) inhibitors or glucaogon like peptide 1 receptor agonist (GLP-1 RA).

\section{Empagliflozin/linagliptin-fixed dose combination}

Empagliflozin has been recently approved (February 2015) in a combination therapy with linagliptin (LINA) (a DPP-4 inhibitor). ${ }^{47}$ This medication, under the brand name Glyxambi $^{\circledR}$ (Boehringer Ingelheim Pharmaceuticals, Inc., Ridgefield, CT, USA), is available as $10 \mathrm{mg}$ EMPA/5 mg of LINA or $25 \mathrm{mg}$ empagliflozin/5 mg of LINA. ${ }^{44}$ Boehringer Ingelheim manufactures both EMPA and LINA.

In a study, EMPA 25/LINA 5 mg $(n=134)$ and EMPA/ LINA $10 \mathrm{mg} / 5 \mathrm{mg}(\mathrm{n}=135)$ were utilized in drug-naïve type 2 diabetes with a baseline $\mathrm{HbA}_{1 \mathrm{c}}$ of $7.99 \%$ and $8.04 \%$, respectively. $\mathrm{HbA}_{1 \mathrm{c}}$ improved by $1.08 \%$ (EMPA/LINA $25 \mathrm{mg} / 5 \mathrm{mg}$ ) and 1.24\% (EMPA/LINA $10 \mathrm{mg} / 5 \mathrm{mg}$ ) and 
body weight reductions of 2.0 and $2.7 \mathrm{~kg}$ were seen. ${ }^{48}$ More people achieved an $\mathrm{HbA}_{1 \mathrm{c}}$ of less than $7 \%$ at 24 and 52 weeks in the combination therapy than the individual medications. ${ }^{48}$

This study group also completed a trial with fixed-dose EMPA/LINA as add-on to metformin. In this 52 week trial, subjects were randomized to EMPA/LINA $25 \mathrm{mg} / 5 \mathrm{mg}$ $(\mathrm{n}=137)$, EMPA/LINA $10 \mathrm{mg} / 5 \mathrm{mg}(\mathrm{n}=136)$, or the individual medications, EMPA 25 ( $n=141)$, EMPA $10 \mathrm{mg}(\mathrm{n}=140)$, or LINA $5 \mathrm{mg}(\mathrm{n}=132)$. The fixed combinations had greater $\mathrm{A}_{1 \mathrm{c}}$ reductions despite slightly lower starting $\mathrm{A}_{1 \mathrm{c}} \mathrm{s}$. EMPA/ LINA $25 \mathrm{mg} / 5 \mathrm{mg}$ reduced $\mathrm{A}_{1 \mathrm{c}}$ by $1.19 \%$, and EMPA/LINA $10 \mathrm{mg} / 5 \mathrm{mg}$ reduced $\mathrm{A}_{1 \mathrm{c}}$ by $1.08 \%$. The single agents reduced $\mathrm{A}_{1 \mathrm{c}} 0.63 \%, 0.66 \%$, and $0.7 \%$, respectively. Weight loss was similar in the fixed combination groups and single agent EMPA. The 24-week weight loss was $3.0 \mathrm{~kg}$ in EMPA/LINA $25 \mathrm{mg} / 5 \mathrm{mg}, 2.6 \mathrm{~kg}$ in EMPA/LINA $10 \mathrm{mg} / 5 \mathrm{mg}, 3.2 \mathrm{~kg}$ in EMPA $25 \mathrm{mg}, 2.5 \mathrm{~kg}$ in EMPA $10 \mathrm{mg}$, and $0.7 \mathrm{~kg}$ in LINA 5 mg. ${ }^{49}$

Hypoglycemic risk and adverse reactions, such as urinary tract infections, pancreatitis, and cholesterol changes were monitored in the aforementioned trials. ${ }^{48,49}$ Results demonstrated that there was no increase in severe hypoglycemia even with the fixed dose combination. There was no increase or change in adverse reactions when these two medications were administered simultaneously vs their individual adverse reaction profiles. ${ }^{48,49}$

\section{Empagliflozin and renal indices}

When the SGLT2 inhibitors were first released, there was some clinical concern that permissive glucosuria would contribute to advancing nephropathy despite some reassurance from the experience of people with familial renal glucosuria. In early clinical studies, there is some evidence that the contrary may be true. In a series of studies, patients with type 2 diabetes with preexisting microalbuminuria were randomized to EMPA 10, $25 \mathrm{mg}$, or placebo. Those on EMPA had reported decreased urinary albumin to creatinine ratio by $30 \%$ and $25 \%$, respectively, compared to placebo. ${ }^{50}$ This suggests that despite permissive hyperglycemia, there may be some renoprotection from this class of medications. This is still exploratory and would need to be repeated.

Another study ${ }^{51}$ explored the effect of EMPA on the intraglomerular hemodynamic profile and hyperfiltration in patients with type 1 diabetes. In this study, ${ }^{52} 27$ patients who had hyperfiltration but no hypertension or albuminuria, and 13 who had a normal GFR (and no hypertension/albuminuria) were given 8 weeks of EMPA $25 \mathrm{mg}$ daily. The investigators found that there was an increase in renal afferent resistance in the hyperfiltrators with a reduction in glomerular hydrostatic pressure, but no change in renal efferent resistance. These parameters were not affected by EMPA in the normal GFR controls. This provides some evidence that EMPA could have some renoprotective effects and should be investigated further. ${ }^{52}$

\section{Empagliflozin in type I diabetes}

Empagliflozin may play a role in the treatment of type 1 diabetes. A recent expert opinion paper summarized the potential use of SGLT2 inhibitors in patients with type 1 diabetes. ${ }^{53}$ Early studies have shown that use of SGLT2 inhibitors in type 1 diabetes can reduce $\mathrm{HbA}_{1 \mathrm{c}}$ in 8 weeks by $0.4 \%$ in those with a baseline of $8.0 \%$. Further, there was a statistical reduction in symptomatic hypoglycemia and total insulin dose. Mean urinary glucose excretion increased from $19 \mathrm{~g} / 24 \mathrm{~h}$ to $134 \mathrm{~g} / 24 \mathrm{~h}$. Weight decreased by $2.7 \mathrm{~kg}$, and there was also a reduction in waist circumference of $3.8 \mathrm{~cm}$. There were two reported cases of diabetic ketoacidosis, but they were associated with a pump failure and an episode of gastroenteritis. ${ }^{51}$ This appears to be a significant finding that may be related to normoglycemia and relative insulinopenia. This is currently under further investigation.

Recently, it was shown that SGLT2 inhibition attenuated renal hyperfiltration in subjects with type 1 diabetes by affecting tubular glomerular feedback mechanisms and, potentially, by its effects on nitric oxide. ${ }^{54,55}$ Further study is needed to determine the safety and long-term efficacy of this medication in type 1 diabetes mellitus.

\section{Clinical summary of EMPA}

The SGLT2 inhibitors are a welcome addition to the diabetes treatment armamentarium. EMPA addresses hyperglycemia from a noninsulin centric manner, which can be complementary to other agents and can be used even in those who no longer make insulin. Further, EMPA appears to have significant nonglycemic benefits including weight loss, reduction in blood pressure, and reduction in uric acid. This is balanced by minor changes in lipid parameters and an increase in urinary tract and genital mycotic infections. While it was suspected by some physicians (including the authors of this paper) that glucosuria would result in adverse renal consequences, early studies actually support renal benefit from SGLT2 inhibitors from reduced renal hyperperfusion and reduction in protein excretion. With this profile EMPA and the other SGLT2 inhibitors are significant additions to the market for diabetes treatment. 
This is reflected by inclusion of this class of medications in the 2015 American Association of Clinical Endocrinologists treatment guidelines. ${ }^{56}$ While the role of these agents in type 1 diabetes is unclear, anecdotal reports suggest that when used carefully these agents have a significant clinical benefit in type 1 diabetes.

\section{Conclusion}

Empagliflozin (along with the other SGLT2 inhibitors) is a novel addition to treatment of type 2 diabetes. Empagliflozin has glycemic and nonglycemic benefits. Glycemic benefits are obvious with evidence based on lowering an $\mathrm{HbA}_{1 \mathrm{c}}$ in an insulin-independent mechanism. Nonglycemic benefits include weight loss, blood pressure lowering, and decreased urinary protein excretion.

Diabetes is a progressive disorder, and combination therapy is expected as the disease progresses. Reducing the medication burden can help to improve adherence to complicated medication regimens. Glyxambi ${ }^{\circledR}$ is a novel combination therapy option that includes new treatment pathways that do not rely on intact insulin secretion. Current guidelines recommend combination therapy early in type 2 diabetes therapy to address the variety of pathophysiologic mechanisms. ${ }^{51}$ Conversely, the cost of these agents may be prohibitive for some patients. Depending on drug coverage and generic availability, cost should be considered as increased cost could cause decreased adherence and disease management.

SGLT2 inhibitors may be seen in T2DM patients who have failed to reach $\mathrm{HbA}_{1 \mathrm{c}}$ goals with single drug therapy with metformin and life style changes. The use of SGLT2 inhibitors can be explored in patients who may need assistance with weight loss and potential improvement in blood pressure. They may be tried as an initial add-on to metformin or, in weight loss, or may be used after failure of a GLP-1. These should not be used in patients with renal failure, those at increased risk of candidiasis infections, or those at risk for hypotension.

In the future, SGLT2 inhibitors may be found in additional combination products. They may be found useful in patients with type 1 diabetes. Further studies are needed to explore further benefits or risks with SGLT2 inhibitors.

\section{Disclosure}

Jay H Shubrook has received research support from Sanofi and has served as a consultant to Astra Zenenca, NovoNordisk and Eli Lilly. The authors report no other conflicts of interest in this work.

\section{References}

1. International Diabetes Federation. Diabetes Atlas. Available from: http://www.idf.org/diabetesatlas. Accessed January 3, 2015.

2. World Health Organization. Facts and figures about diabetes. Available from: http://www.who.int/diabetes/facts/en/. Accessed January 3, 2015.

3. DeFronzo RA. From the triumvirate to the ominous octet: a new paradigm for the treatment of type 2 diabetes mellitus. Diabetes. 2009; 58:773-795.

4. DeFronzo RA, Davidson JA, Del Prato S. The role of the kidneys in glucose homeostasis: a new path towards normalizing glycaemia. Diabetes Obes Metab. 2012;14(1):5-14.

5. Gerich JE. Role of the kidneys in normal glucose homeostasis and in the hyperglycemia of diabetes mellitus: therapeutic implications. Diabetic Med. 2010;27(2):136-142.

6. Gallo LA, Wright EM, Vallon V. Probing SGLT2 as a therapeutic target for diabetes: basic physiology and consequences. Diab Vasc Dis Res. 2015;12(2):78-89.

7. Nauck MA. Update on developments with SGLT2 inhibitors in the management of type 2 diabetes. Drug Des Devel Ther. 2014;8:1335-1380.

8. Wright EM, Loo DD, Hirayama BA. Biology of human sodium glucose transporters. Physiol Rev. 2011;91(2):733-794.

9. Tabatabai NM, Sharma M, Blumenthal SS, et al. Enhanced expressions of sodium-glucose co-transporters in the kidneys of diabetic Zucker rats. Diabetes Res Clin Pract. 2009;83:e27-e30.

10. Vallon V, Rose M, Gerasimova M, et al. Knockout of Na-glucose transporter SGLT2 attenuates hyperglycemia and glomerular hyperfiltration but not kidney growth or injury in diabetes mellitus. Am J Physiol Renal Physiol. 2013;304:F156-F167.

11. Rahmoune H, Thompson PW, Ward JM, et al. Glucose transporters in human renal proximal tubular cells isolated from the urine of patients with non-insulin dependent diabetes. Diabetes. 2005;54:3227-3234.

12. Mering J. Ueber kuenstlichen diabetes [Through artificial diabetes]. Centralbl Med Wiss. 1886; xxxii:531.

13. Ehrenkranz JR, Lewis NG, Kahn CR, Roth J. Phlorizin: a review. Diabetes Metab Res Rev. 2005;21(1):31-38.

14. Abdul-Ghani MA, Norton L, Defronzo RA. Role of the sodium-glucose cotransporter 2 (SGLT2) inhibitors in the treatment of type 2 diabetes. Endocr Rev. 2011;32(4):515-531.

15. Nair S, Wilding JP. Sodium glucose cotransporter 2 inhibitors as a new treatment for diabetes mellitus. J Clin Endocrinol Metab. 2010; 19(2):34-42.

16. Santer R, Kinner M, Lassen CL, et al. Molecular analysis of the SGLT2 gene in patients with renal glucosuria. J Am Soc Nephrol. 2003; 14(11):2873-2882.

17. Turk E, Zabel B, Munidos S, Dyer J, Wright EM. Glucose/galactose malabsorption caused by a defect in the $\mathrm{Na}+$ glucose cotransporter. Nature. 1991;350:354-356.

18. Liang Y, Arakawa K, Ueta K, et al. Effect of canagliflozin on renal threshold, glycemia, and body weight in normal and diabetic animal models. PLoS One. 2012;7(2):e30555. Available from: http://www. ncbi.nlm.nih.gov/pmc/articles/PMC3280264/pdf/pone.0030555.pdf. Accessed September 10, 2015.

19. Whaley JM, Tirmenstein M, Reilly TP, et al. Targeting the kidney and glucose excretion with dapagliflozin: preclinical and clinical evidence for SGLT2 inhibition as a new option for treatment of type 2 diabetes mellitus. Diabetes Metab Syndr Obes. 2012;5:135-148.

20. www.FDA.gov [homepage on the Internet]. FDA News Release. FDA Approves Invokana to treat Type 2 diabetes. Released March 29, 2013. Available from: http://www.fda.gov/NewsEvents/Newsroom/ PressAnnouncements/ucm345848.htm. Accessed October 3, 2015.

21. U.S. Department of Health and Human Services, Food and Drug Administration. FDA approves Jardiance to treat type 2 diabetes [FDA News Release]. Silver Spring, MD: U.S. Department of Health and Human Services, Food and Drug Administration; 2014 [August 1]s. Available from: http://www.fda.gov/NewsEvents/Newsroom/PressAnnouncements/ucm407637.htm. Accessed April 12, 2015. 
22. Grempler R, Thomas L, Eckhardt M, et al. Empagliflozin, a novel selective sodium glucose cotransporter-2 (SGLT-2) inhibitor: characterization and comparison with SGLT-2 inhibitors. Diabetes Obes Metab. 2012;14:83-90.

23. Jardiance ${ }^{\circledR}$ [package insert]. Ridgefield, CT: Boehringer Ingelheim Pharmaceuticals, Inc; 2014

24. Thomas L, Grempler R, Eckhardt M, et al. Long-term treatment with empagliflozin, a novel, potent and selective SGLT-2 inhibitor, improves glycaemic control and features of metabolic syndrome in diabetic rats. Diabetes Obes Metab. 2012;14(1):94-96.

25. Seman L, Macha S, Nehmlz G, et al. Empagliflozin (BI 10773), a potent and selective SGLT2 inhibitor, induces dose dependent glucosuria in healthy subjects. Clin Pharmacol Drug Dev. 2013;2:152-161.

26. Sarashina A, Koiwai K, Seman L, et al. Safety, tolerability pharmacokinetics and pharmacodynamics of single doses of empagliflozin, a sodium glucose cotransporter 2 (SGLT2) inhibitor, in healthy Japanese subjects. Drug Metab Pharmacokinet. 2013;28(3): 213-219.

27. Heise T, Seewaldt-Becker E, Macha S, et al. Safety, tolerability, pharmacokinetics and pharmacodynamics following 4 week' treatment with empagliflozin once daily in patients with type 2 diabetes. Diabetes Obes Metab. 2013;15(7):613-621.

28. Heise T, Seman L, Macha S, et al. Safety, tolerability, pharmacokinetics and pharmacodynamics of multiple rising doses of empagliflozin in patients with type 2 diabetes mellitus. Diabetes Ther. 2013; 4(2): 331-345.

29. Ferrannini E, Seman L, Seewaldt-Becker E, Hantel S, Pinnetti S, Woerle HJ. A phase IIb, randomized placebo controlled study of the SGLT2 inhibitor empagliflozin in patients with type 2 diabetes. Diabetes Obes Metab. 2013;15(8):721-728.

30. Macha S, Rose P, Mattheus M, et al. Pharmacokinetic, pharmacodynamics and safety of empagliflozin, a sodium glucose cotransporter 2 (SGLT 2) inhibitor in subjects with renal impairment. Diabetes Obes Metab. 2014;16(3):215-222.

31. Macha S, Rose P, Mattheus M, et al. Pharmacokinetics, safety and tolerability of empagliflozin, a soidium glucose co-transporter 2 (SGLT2) inhibitor in patients with hepatic impairment. Diabetes Obes Metab. 2014;2:118-123.

32. Polidori D, Sha S, Mudaliar S, et al. Canagliflozin lowers postprandial glucose and insulin by delaying intestinal glucose absorption in addition to increasing urinary glucose excretion. Diabetes $C a$. 2013;36:2154-2161.

33. Merovci A, Solis-Herrera C, Daniele G, et al. Dapagliflozin improves muscle insulin sensitivity but enhances endogenous glucose production. $J$ Clin Invest. 2014;124(2):509-514.

34. Ferrannini E, Ramos SJ, Salsali A, Tang W, List JF. Dapagliflozin monotherapy in type 2 diabetic patients with inadequate glycemic control by diet and exercise: a randomized, double-blind, placebocontrolled, phase 3 trial. Diabetes Care. 2010;33:2217-2224.

35. Roden M, Weng J, Eilbracht J, et al. Empagliflozin monotherapy with sitagliptin as an active comparator in patients with type 2 diabetes: a randomised, double-blind, placebo-controlled, phase 3 trial. Lancet Diabetes Endocrinol. 2013;1(3):208-219.

36. Roden M, Weng J, Merker L, et al. Empagliflozin monotherapy in drug naïve patients with type 2 diabetes (EMPA-REG-EXTEND MONO) [poster 264-OR]. Poster presented at: ADA Scientific Sessions 2014, San Francisco, CA, USA.

37. Häring HU, Merker L, Seewaldt-Becker E, et al. Empagliflozin as an add-on to metformin plus sulfonylurea in patients with type 2 diabetes: a 24-week, randomized, double-blind, placebo-controlled trial. Diabetes Care. 2013;36(11):3396-3404.

38. Häring HU, Merker L, Seewaldt-Becker E, et al; EMPA-REG MET Trial Investigators. Empagliflozin as add-on to metformin in patients with type 2 diabetes: a 24-week, randomized, double-blind, placebocontrolled trial. Diabetes Care. 2014;37(6):1650-1659.
39. Ridderstråle M, Andersen KR, Zeller C, et al. Comparison of empagliflozin and glimepiride as add-on to metformin in patients with type 2 diabetes: a 104-week randomised, active-controlled, double-blind, phase 3 trial. Lancet Diabetes Endocrinol. 2014;2(9):691-700.

40. Kovacs CS, Seshiah V, Swallow R, et al. Empagliflozin improved glycaemic and weight control as add-on therapy to pioglitazone or pioglitazone plus metformin in patients with type 2 diabetes: a 24-week, randomized, placebo-controlled trial. Diabetes Obes Metab. 2013;16(2):147-158.

41. Rosenstock J, Jelaska A, Frappin G, et al. Improved glucose control with weight loss, lower insulin doses, and no increased hypoglycemia with empagliflozin added to titrated multiple daily injections of insulin in obese inadequately controlled type 2 diabetes. Diabetes Care. 2014;37(7):1815-1823.

42. Kim SY1, Guevara JP, Kim KM, Choi HK, Heitjan DF, Albert DA. Hyperuricemia and coronary heart disease: a systematic review and meta-analysis. Arthritis Care Res (Hoboken). 2010;62(2):170-180. doi:10.1002/acr.20065.

43. Barnett AH, Mithal A, Manassie J, et al. Efficacy and safety of empagliflozin added to existing antidiabetes treatment in patients with type 2 diabetes and chronic kidney disease: a randomised, doubleblind, placebo-controlled trial. Lancet Diabetes Endocrinol. 2014; 2(5):369-384.

44. Vasilakou D, Karaglannis T, Athanasladou E, et al. Sodium-glucose cotransporter 2 inhibitors for type 2 diabetes a systematic review and meta-analysis. Ann Intern Med. 2013;159:262-274.

45. Toto $\mathrm{RD}$, Wanner $\mathrm{C}$, Gerich J, et al. No overall increase in volume depletion events with empagliflozin (EMPA) in a pooled analysis of more than 11,000 patients with type 2 diabetes (T2DM). J Am Soc Nephrol. 2013;24(Suppl):Abstract SA-PO373.

46. Bonner C, Kerr-Conte I, Gmys V, Quealat G, Moerman E, et al. Inhibition of the glucose transporter SGLT2 with dapagliflozin in pancreatic alpha cells triggers glucagon secretion. Nat Med. 2015;121:512-517.

47. Glyxambi ${ }^{\circledR}$ [package insert]. Ridgefield, CT. Boehringer Ingleheim Pharmaceuticals, Inc; January 2015.

48. Lewin A, DeFronzo R, Patel S, et al. Initial combination therapy with empagliflozin and linagliptin in subjects with type 2 diabetes. Diabetes Care. 2015;38:394-402.

49. DeFronzo R, Lewin A, Patel S, et al. Fixed dose combination of empagliflozin and linagliptin as second-line therapy in subjects with type 2 diabetes inadequately controlled on metformin. Diabetes Care. 2015;38:384-393.

50. Cherney DZ, Eynatten MV, Lund SS, et al. Sodium glucose cotransporter 2 (SGLT2) inhibition with empagliflozin reduces microalbuminuria in patients with type 2 diabetes [Poster 1125-P]. Poster presented at: ADA 74th Scientific Sessions 2014, San Francisco, CA, USA.

51. Perkins BA, Cheney DZ, Patridge H, et al. Sodium glucose co-transporter 2 inhibitor and glycemic control in type 1 diabetes: results of an 8 week open label proof of concept trial. Diabetes Care. 2014;37(5): $1480-1483$.

52. Skrtić M, Yang GK, Perkins BA, et al. Characterisation of glomerular haemodynamic responses to SGLT2 inhibition in patients with type 1 diabetes and renal hyperfiltration. Diabetologia. 2014; 57(12):2599-2602.

53. Lamos E, Younk L, Davis S. Emapgliflozin, a sodium glucose cotransporter 2 inhibitor, in the treatment of type 1 diabetes. Expert Opin Investig Drugs. 2014;23:875-882.

54. Cheney DZ, Perkins BA, Soleymanlou Y, et al. The effect of empagliflozin on arterial stiffness and heart rate variability in subjects with uncomplicated type 1 diabetes mellitus. Cardiovasc Diabetol. 2014;13:28.

55. Cheney DZ, Perkins BA, Soleymanlou Y, et al. Renal hemodynamic effect of sodium-glucose cotransporter 2 inhibition in patients with type 1 diabetes mellitus. Circulation. 2014;129:587-597. 
56. AACE/ACE Comprehensive Diabetes Management Algorithm 2015 and AACE/ACE Diabetes Clinical Practice Guidelines. Available from: https://www.aace.com/publications/algorithm. Accessed April 4, 2015.

57. McGill J. The SGLT2 inhibitor empagliflozin for the treatment of type 2 diabetes mellitus: a bench to bedside review. Diabetes Ther. 2014;5:43-63.
58. Miller E, Shubrook JH. Role of the kidneys and sodium glucose co-transporter 2 (sglt2) inhibitors in the treatment of type 2 diabetes mellitus. Osteopathic Family Physician. 2015;1(5):10-30.

\section{Publish your work in this journal}

Drug Design, Development and Therapy is an international, peerreviewed open-access journal that spans the spectrum of drug design and development through to clinical applications. Clinical outcomes, patient safety, and programs for the development and effective, safe, and sustained use of medicines are a feature of the journal, which has also been accepted for indexing on PubMed Central. The manuscript management system is completely online and includes a very quick and fair peer-review system, which is all easy to use. Visit http://www.dovepress.com/testimonials.php to read real quotes from published authors.

Submit your manuscript here: http://www.dovepress.com/drug-design-development-and-therapy-journal 